\title{
Learning Method and Teaching Material of Plus Curriculum In The Madrasah Aliyah Darul Ulum, Banda Aceh: An Ethnographic Study
}

\author{
Syarfuni*, Nuruddin, Zainal Rafli \\ Language Education, Postgraduate of Universitas Negeri Jakarta, Indonesia \\ Corresponding Author: Syarfuni, E-mail: syarfuni_lt16s3@mahasiswa.unj.ac.id
}

\begin{tabular}{l} 
ARTICLE INFO \\
\hline Article history \\
Received: January 19, 2019 \\
Accepted: April 20, 2019 \\
Published: June 30, 2019 \\
Volume: 10 Issue: 3 \\
Advance access: May 2019 \\
\hline Conflicts of interest: None \\
Funding: The research is financed \\
by Indonesia Endowment Fund for \\
Education (LPDP) \\
\hline
\end{tabular}

Key words:

Learning Method,

Teaching Material,

Plus Curriculum,

Learning English,

Approaches,

Curriculum

\begin{abstract}
This study is to understand the teaching materials, approaches and methods used in the plus curriculum in the teaching English as compulsory subject in the Madrasah Aliyah Darul Ulum Banda Aceh. An ethnography method was purposefully used where four participants were involved for an in-depth interview and classroom observation. The result revealed that the approaches were used namely scientific and communicative approach. The method becomes priority were lecture method, demonstration, discussion, simulation, grammar translation method, direct method, debate, and role play. Whereas the teaching material were sourced from the technical school guiding book, relevant technical books, magazines, visual-based teaching, audio-visual based and multimedia-based learning sources. Therefore, this is one of evidences that the using of teaching material, approaches and method under the plus curriculum can mediate the Madrasah Aliyah students' English learning outcomes. This may put into account due to the specific educational and cultural issue and practices in those private Madrasah Aliyah. Moreover, it can be recommended to other schools in Banda Aceh to apply such an innovative and combination curriculum contents; local school and national curriculum instruction. A further ethnographic research is needed to investigate how teachers and principals prepare or determine teaching materials and learning model prior to the learning process conducted.
\end{abstract}

\section{INTRODUCTION}

\section{Background of Study}

All Madrasah Aliyahs (Islamic Senior High School) are compulsory to implement national curriculum instructed by the Ministry of Education as an official document. However, the Madrasah Aliyah Darul Ulum Banda Aceh as one of private Islamic schools is allows apply self-designed curriculum for $50 \%$ and $50 \%$ other are from national curriculum. This combination is the uniqueness one. The process of combining two curricula is called a plus curriculum. Although self-designed curriculum has long been a hotly debated issue in curriculum design and development but the school still using the curriculum as a guide in teaching and learning, the curriculum implementation requires good cooperation among students, teachers, and teaching materials to achieve the learning goals (Yusuf, H, 2014).

The plus curriculum is a combination of the national and the pesantren (Islamic boarding) curriculum. The national curriculum was used as guidelines to implement teaching and learning activities at the school whereas the pesantren curriculum was used to support teaching and learning at pesantren. The purpose of applying the plus curriculum is that the students are expected to have multiple skills. Especially in English subject, the students are expected able to master four language skills such as listening, speaking, reading, and writing. This was done in order to the students can continue their studies at the university level, therefore, the school reformed the curriculum by integrating national curriculum and boarding school. The output of implementing curriculum showed that the school becomes one of the favorite schools in the Banda Aceh.

Several research has proven which the curriculum reform has some positive effect on learning the outcome such as conducted by Tong et al. (2014), B Strick (2014), John, Yvonne J. (2015), Kahveci, Nihat Gürel; Atalay, Özlem (2015), Suryadi, B., Ekayanti, F., \& Amalia, E (2018), LaMotte, M. (2018), Lau, Wing Chi Margaret; Grieshaber, Susan (2018). From various research results, it showed that curriculum reform have good impact on learning outcomes.

Previous studied have done about curriculum reform such as (Vidergor, Givon, \& Mendel, 2019), strategies, the func- 
tion of the reform, and the curriculum coherence (Pietarinen, Pyhältö, \& Soini, 2016), shared sense-making strategies in curriculum reform (Pietarinen et al., 2016); understanding the impact of government's role in the change process of the reform (Wong \& Cheung, 2015), how Chinese educators and teachers implement curriculum reform in mathematics classrooms (Zhao, Ah, Mok, \& Cao, 2016), the perceptions and experiences of School Management Teams (SMTs) regarding their role in managing the implementation of the National Curriculum Statement (NCS) as curriculum change (Mafora, Phorabatho, Mafora, \& Phorabatho, 2017); and the method of curriculum reform in colleges and universities (Song, 2018). However, studies related to the application of the basic curriculum components (objective, knowledge, school learning experiences and evaluation) have rarely been investigated related to cultural issue. Therefore, Relevance to that case, it is needed to investigate part of curriculum components specifically learning method and teaching material used in implementing the plus curriculum.

\section{The Research Problem}

The current study addresses this gap research by exploring only two basic curricula in teaching English. The following research questions are:

1) What are the approaches and methods used by the English teachers in the plus curriculum?

2) What are the teaching materials used by the English teachers in the plus curriculum?

\section{Objectives of the Study}

The objectives of this study are to understand deeply the teaching method and material used in the classroom in teaching English using the plus curriculum.

\section{Literature Review}

\section{Curriculum reform}

Starting from the pre-independent period with a very simple form, and the period of independence which was continuously refined namely in 1947, 1952, 1964, 1968, 1975, 1984, 1994, 2004, 2006, and 2013 (Machali, I. 2014). While the curriculum reform at the school began before the 2013 curriculum was approved by the government. This curriculum is called plus curriculum. Curriculum reform remains in the national curriculum but the school adapts to the vision and mission of the MA Darul Ulum school in Banda Aceh.

There are many evidences about curriculum reform contribute toward the improvement of learning result (Alghamdi, A. (2017), (Miliyawati, B. 2016), (Paulo, A., \& Tilya, F., 2014), (Fenwick, 2017), (Fenwick, L. 2011), benefit of curriculum reform can raise students' the ability to analyze and solve problems (He, C. L. 2013), improvement and teachers' motivation (Haruthaithanasan, T., 2018). Those conclusion was that implementation of curriculum reform was most effective when it used supplemental strategies rather than used only the national curriculum.

\section{Plus Curriculum and National Curriculum in a MA Darul Ulum}

Plus curriculum is the innovation curriculum designed by MA Darul based on the theoretical under national curriculum, especially in English language teaching, that language teaching aim at using foreign language to understand both oral and written the recount, narrative text, and procedure text (2013 Curriculum). Although the national curriculum standard of competence is considered good for improving English language skills but to produce graduates who are able to use fluent English both oral and written, the school conducts the latest curriculum innovation in learning. The purpose of curriculum innovation, especially English language lessons, emphasizes speaking and listening skills more than the national curriculum which suppresses reading and writing skills.

\section{Learning Method}

Learning method is a way that teachers use to optimize the learning process in order to achieve the expected learning goals (Mariyaningsih, N \& Hidayati, M (2018). Furthermore, learning strategies are still conceptual and various methods of learning are used to implement them. A strategy is a series of activities that must be carried out to achieve certain goals (Sanjaya, 2008). It is said to be series of sequences because a strategy is basically still abstract in nature but it does not lead to practical matters. Therefore, it is still a plan or a comprehensive picture. To achieve learning goals, an effective strategy is needed to achieve learning objectives. Without an appropriate strategy, right with learning activities, it can be ascertained that learning objectives will be difficult to achieve.

Some terms in learning strategies such as approaches, methods, techniques, and learning tactics. Often used with the same understanding; approaches and methods are interpreted with the same meaning, and in fact, the term method is interpreted the same as the meaning of the approach, as well as the terms techniques and methods. Actually, the three terms have different meanings, even though the application is interrelated. Related to this, Anthony (1963:63-7) gives the definition of these three hierarchical elements. According to Anthony, the approach is a series of assumptions relating to the nature of language, learning, and teaching. The method is defined as the overall plan for a systematic presentation of language based on a chosen approach. The technique is a special activity in the class that is consistent with a method. Such as Richards and Rodger (2000) term the method as an umbrella to capture design approaches, redefined procedures. Prabhu (1990) views methods as activities in the classroom as well as theories that provide information on classroom activities. But in general, the definition still refers to the term understanding that Anthony put forward earlier.

\section{Teaching Material}

In teaching practice, teaching materials have an important role that functions as material used by teachers and students 
for learning (Mukalel, Joseph C. 2007:118). Therefore, one of the tasks of educators is to provide a pleasant learning atmosphere. Educators must look for ways to make learning fun and put aside threats during the learning process. One way to make learning fun is to use teaching materials that are fun too, namely teaching materials that can make students feel interested and happy to learn both during class and after. Teaching materials are basically all materials (both information, tools, and text) that are arranged systematically, which displays the full figure of competencies that students will master and use in the learning process with the aim of planning and reviewing the implementation of learning (Prastowo, 2012). Learning materials or materials are basically contents of the curriculum, which are in the form of subjects or fields of study with topics/subtopics and details (Ruhimat 2011). Furthermore, Depdiknas (2006) defines teaching materials or instructional materials in broad outline consisting of knowledge, skills, and attitudes that students must learn in order to achieve predetermined competency standards. Based on some of the opinions above, the authors conclude that teaching materials are a set of subject matter that can help achieve curriculum objectives that are arranged systematically and intact so as to create a pleasant learning environment, facilitate students to learn, and teach teachers.

\section{METHOD}

As stated, this study attempted to understand the implementation of plus curriculum in teaching English as a foreign language. An ethnographic study used as the method. The data collection involves portraying aspects of a culture that concern the core of learning method and teaching material used in the classroom. Ethnographic studies are aimed at getting a localized understanding of cultural processes, or meaning-making, as it occurs from one vantage point (Maanen, 2011).

\section{Research Setting}

The place under investigation is a boarding school that combines the pesantren (Islamic boarding school) curriculum and school curriculum. It is located in Banda Aceh city with a population of around 244,463, Aceh Province, Indonesia. The school was founded in 1990 and has a good academic reputation in the Banda Aceh area. There are five English teachers at the school. As for the high school class, there are 35-40 students in one class, and usually, an English teacher taught 2 classes. The overall teaching hours per week are 2 for level 10, level 11, and level 12 students.

\section{Interview}

The author uses two types of semi-structured interviews, informal/ethnographic interviews and in-depth interviews conducted to meet different research goals. Continuous interviews between researchers and informants throughout ongoing interactions such as discussing (Spradley, 1980). Informal interviews are carried out in the normal way that is unplanned casual manner and is not approved by the au- dio. Data collected through informal interviews are then included in field notes. While informal interviews are used to get knowledge related to cultural and social background and place of research Formal interviews were conducted to get the opinions of informants about the questions that were asked to be asked for cycles (Borg, 2011). The interview schedule was informed by an analysis of the informant's response to the previous interview. Each formal interview lasts 1 hour and is completed audio with the informant's permission. Interviews were conducted in Indonesia.

\section{Classroom Observation}

Observation data were collected to get a learning behaviors during the learning process. Observations were done in the second grade with the permission of the principal and English teacher. For each session for one hour, do it for $45 \mathrm{~min}-$ utes for 4 meetings. This activity was conducted to strengthen interview data related to the use of teaching methods and materials used in the plus curriculum.

\section{Data Analysis}

Analysis of ethnographic data collected from the results of the study was carried out by following the pattern (Spradley, 1975). In general, it includes four stages, namely domain analysis, taxonomic analysis, component analysis, and analysis of cultural themes.

\section{RESULT AND DISCUSSION}

The findings of this study will be presented in two separate sections namely learning method and teaching material used in implementing of Plus curriculum. The results demonstrate as followed:

\section{Teaching Materials}

Teaching materials are a set of materials/substances teaching materials that are arranged systematically, showing the whole figure of the competencies which students will learn in learning activities (Sugiyono, 2012) therefore, it cannot replace the teaching and learning process at school because teaching material is an important part of teaching and learning ( $\mathrm{Ru}-$ kayah, R., Tolla, A., \& Ramly, R. 2018). The type of teaching material used namely textbooks, relevant textbooks, student worksheets, newspapers, magazines, ICT-based teaching materials, and internet. The selection of various teaching materials has a positive effect on students' abilities in mastering lesson. This statement is consistent with the results of the study Adelowo (2015) that the use of instructional resources like audio, visual and audio-visual materials can make the students maximize their performance in the English Language.

The types of textbooks used are compulsory school textbooks and additional textbooks that are relevant to student needs, teacher needs, syllabus, and semester examinations. The use of textbooks in schools in the learning process is mandatory and has had a positive impact on teachers and students. The benefits obtained are teachers or students who want 
to learn or repeat the lesson so they can read directly in the textbooks at the previous meeting lessons or the next meeting lesson. Though textbook language presented to students in textbooks is a poor representation of the real thing as (Gilmore, 2007) but the use of textbooks is increasing because it provides convenience to the teacher (Hanifa, R. 2018). Beside it does not only control what is to be taught but also determine the teaching methodology and evaluation (Huda, M. 2017).

In addition to using compulsory school textbooks, teachers use other textbooks relevant to lessons that do not deviate from the school syllabus. The selection of relevant textbooks is based on the authority given by the school to the teacher to choose teaching materials. Ünal, Çeliköz, \& Sarı, (2017) that there are significant differences in the constructs of technical perspectives on learner autonomy. Doğan \& Hakk1, (2017) revealed that the instructors had highly positive views on different aspects of learner autonomy. Beside learner autonomy promotes human rights, and it is an effective approach to language learning (Palfreyman, 2003). This illustrates give important signals that teachers are given the authority to choose teaching materials that can have a positive impact on student learning outcomes.

Another teaching material used in teaching was students' worksheets. It gives a higher positive effect on the success of students. The result now provides evidence to the worksheets in teaching of adjectives as grammatical components (Ulaş, A. H., Sevim, O., \& Tan, E. 2012). Others have shown that worksheet development helps the students to develop concepts, to obtain information about concepts learned through a systematic learning process, train the students to discover and develop process skills, and guide the teachers and the students in carrying out the learning process (Purnawati, S., Fauzan, A., \& Rasidin, S. 2019). Next, Newspapers articles and magazines are to be an alternative in choosing teaching materials in the school. The results confirm that this is a good choice for the teachers to familiarize students with authentic sources of reading, retrain them use mother tongue reading skills and make them efficient and independent readers (Bndaka. E., 2007).

Furthermore, the teacher is also given the authority to search for teaching materials sourced from the internet, such as material for teaching skills of speaking, reading, grammar, and vocabulary development. Using the internet as a tool is very helpful for teachers to seek, post, share information for the students; (Elizabeth, Marsh, Rajaram, 2019) and improve learning outcomes (Ünal, Çeliköz, \& Sarı, 2017). Overall, teaching was used by the teacher obtained the most robust result in teaching English at the school.

\section{Learning Method}

Based on interview with the principal and English teachers, the use of communicative and scientific approaches in teaching in classroom has attracted more students to be active in learning. Those approach are mandatory in the plus curriculum aiming to improve intellectual abilities, shaping students' ability to solve problems, creating learning conditions according to needs and developing student characters. Whereas using communicative approach in order to students able to use the English effectively. The Communicative Approach (CA) has been proven to improve students' English skills in language teaching because it develop communicative competencies which include grammatical, sociolinguistics, discourse and strategic skills. As stated by Shah Jabeen, S. (2014) teaching English language using communicative approach becomes essential, and beneficial students to build their speaking skills (Andrade, A., Pereira, S., \& Tolo, A. 2018).

While the application of the scientific approach to learning English is a new approach in the 2013 curriculum. This approach is believed to be able to develop attitudes (affective domain), skills (psycho-motor domains), and knowledge (cognitive domain) of students. This approach focuses on the implementation of learning in the class that underlies the application of methods or scientific procedures. The application of scientific methods there are activities that can be preserved such as observing, asking, exploring, associating and communicating (Kemendikbud, 2013).

Regarding the methods and techniques of learning English, Madrasah Aliyah Darul Ulum gives freedom to teachers to choose and use methods of teaching and learning in teaching. However, it is expected to use learning methods and techniques that are diverse and in accordance with the language skills that will be assisted. Because the selection of appropriate and appropriate methods and techniques in the learning process can provide positive motivation in learning. Therefore, in the learning process, not only the learning tools are prepared but also the selection methods that will be applied in the classroom. The choice of learning methods and techniques must be adapted to the language skills that will be mastered. However, his election still pays attention to students' needs for language.

Based on interviews and observations, it reveals that the teachers used several methods in teaching English at the school namely; lecture method, demonstration; discussion; simulation; grammar translation method, direct method, debate, role play. The lecture method is the process of delivering lessons carried out by teachers with narrative or verbal explanations directly in front of students (Nata. A, 2011). Explain the goals to be achieved, reveal the outlines that will be discussed, and connect between the material that will be presented with the material that has been presented. This method will succeed if you get genuine attention from students, presented systematically, excites, provide opportunities to students.

The teacher selected the simulation, role- play, discussion, debate and discussion method to practice students' speaking and listening skills. Because these skills are absolutely thing which must be mastered by students. The methods encourage students to express ideas through oral. Research results showed the methods were effective in improving students' abilities as stated by Akmal, A. (2018) role-play provides opportunities for students to practice language in class; improve students' speaking (Lutfi, A. A., Sutopo, D., \& Rukmini, D. 2018); improve students' vocabulary (Aclan, E., \& Abdul Aziz, N. 2015).

Next the teacher used grammar translation methods. The method is used by the teacher to teach grammar and English text. It was commonly used to teach grammar with the main characteristics focusing on translation and memorizing vocabulary forms. The teacher usually explains the material using the student's native language in teaching. In line with Richards and Rodgers (2003) regarding the purpose of the translation method 
in learning, that is to make students able to read literature written in the target language, translate mother tongue into fixed language or vice versa and develop writing and reading skills) and also grammar translation methods contribute students' enthusiasm to students in learning English (Durrani, H. 2016).

Direct method, the method is applied to understand the construct of sentences in a text. It will help the students to understand a text through the identification of sentence, such as part of speech, vocabularies, tenses, etc. The process of presenting this method is recorded in four levels; 1) the teacher starts the class with grammar, the grammar is presented deductively then doing the exercises; 2) native languages are written in the mother tongue, students practice the use of rules and vocabulary in the target language, that is often used in a topic; 3 ) to ensure students given the right to explain the difficulties in the lesson (understand); 4) after the correction was given, students prepare to carry out communicative activities. It will enable students to communicate whatever they understand about learning (communication). As discussed, this is the fact that the main principles of the direct method as a means of teaching communication in class, and avoiding the technique of translating the first language into the target language (Richards and Rodgers, 200, p. 38) and research result showed teaching English vocabulary as a foreign language using a direct method has a positive effect on students' vocabulary mastery (Naeini, N. N., \& Shahrokhi, M., 2016).

Finally, the teachers used the question and answer method and lecture.the method are conducted in explaining the relative difficult material for students because they need explanation further to be more understand the lesson. This method in terms of affective domains students can receive learning quite well, and in terms of psychomotor domains, students can be psychomotor active.

From the above discussion, it can be concluded that the English teacher at Madrasah aliyah Darul Ulum used various learning methods and techniques. Variations in methods and learning techniques were chosen based on the language skills taught because each skill has different methods and techniques in learning. Teaching speaking skills are done by actively involving students in speaking English verbally. The involvement of active students is carried out through various activities such as question and answer between teachers and students between students, carrying out public speaking, discussion activities, and conversations in dialogue, monologue, in pairs and in groups. Furthermore, speaking skills were carried out in a mandatory English program in Pesantren. It was done to improve students' ability in speaking English better.

In teaching reading, the method used skimming and scanning. It was used by the teachers in understanding reading texts, seeking general information and specifications. Based on the results study, this method was effective in guiding students to understand the text in the simple or long text to be understood as a discourse. The findings are directly in line with previous findings that skimming-scanning strategies effectively can improve students' reading comprehension (Asmawati, A. 2015), (Yusuf, Q., Yusuf, Y. Q., Yusuf, B., \& Nadya, A. (2017), (Fauzi, I., \& Raya, F. U. P. 2018) (Marliasari, S. 2017).

In teaching writing, students have explained the sentences structure of each type of text learned. Then the teacher asked them to write sentences, paragraphs, and essays. Writing activities are done his/herself, in pairs, and in groups according to the instructions from the source book used. Writing activities was practiced using questioning, the teacher wrote several question while writing on the white board in order to the students undertand the questiong asking by the teacher. students write all the answers submitted by the teacher then they write rephrased in the form of essays based on the type of essay the teacher asks During learning procees, all student involved even though they were shy and lazy in writing. Writing exercise techniques directly train students in knowledge and experience in developing main ideas and supporting sentences into an essay. In writing activities, the teacher acts as a facilitator in answering students' questions related to vocabulary and sentence structure. The author's observations, the questioning method has a positive impact on the results of writing learning that students find it easier to get or develop ideas in writing. Beside that this method can motivate them to write. Etemadzadeh, A., Seifi, S., \& Far, H. R. (2013) was found the questioning method effective to provoke students to write.

Based on the observation on teaching listening, teachers do more in the classroom than in the Language Laboratory. At the Language Laboratory, teaching listening skill was carried out at certain times, such as strengthening listening material during the exam. To practice students' listening skills, the teacher used audiovisual to teach conversation. The listening skill material was obtained by the teacher on the internet that adjusted to the learning topic. The teacher was also assisted by an LDC team to get the right audiovisual media. In the learning process, students are asked to listen carefully to any vocabulary spoken and understand the overall meaning of the conversation being played. Then the teacher and students together answer questions based on the contents of the dialogue. This technique is carried out to facilitate the students in understanding oral texts in English. Techniques seating arrangements vary based on the type of language skills learned. Seating arrangements can be in the form of circles, symposiums, groups, and pairs. In this case students can interact with other friends.

Therefore, the explanation above, it can be concluded the teachers use two approaches dan several methods in the teaching English both in class and outside the classroom. these approaches and methods are believed to improve students' ability to master English, even some research results have proven the effectiveness of those.

\section{CONCLUSION}

This study can note that investigation has prioritized on learning strategies and teaching materials used by the teachers as applying the plus curriculum in teaching English as a foreign language. The conclusion can be drawn as followed: Teaching materials used in the curriculum plus namely school guidebooks, relevant books, visual-based teaching materials like images, charts, diagrams, photographs and presentation slides; audio-visual based such as films, dialogues, conversations, learning CDs, interactive CDs; and multimedia-based teaching materials such as online grammar, online vocabulary, thesaurus, online newspaper, online magazine, and online TOEFL. Learn- 
ing model used by teachers in teaching English use various approaches and methods of teaching. The approaches used by the communicative and scientific approaches. Whereas the methods used such as direct method, grammar-translation method, lecturing method, question and answer, simulation, and debate. The use of variations in learning model is done to achieve higher learning outcomes in accordance with the guidelines in the plus curriculum. The plus curriculum the students are expected to be able to master English both oral and written. Future research on the implementation of the plus curriculum in teaching English as EFL might extend the explanations of how do teachers, principals prepare or determine teaching materials and learning strategies before the learning process begins.

\section{ACKNOWLEDGEMENTS}

The researcher of this study would like to say many thank to the education fund management institution for the funding of this research study. The researcher would also like to thank my supervisors, colleagues, and students who involve in the period of the study. Finally, Without any the contribution from them, this research project study would not be possible.

\section{REFERENCES}

Abuddin Nata. (2011). Perspektif Islam tentang strategi pembelajaran. Jakarta: Kencana

Alghamdi, A. (2017). The effects of an integrated curriculum on student achievement in Saudi Arabia. eurasia journal of Mathematics, Science and Technology Education, 13(9), 6079-6100. doi:10.12973/eurasia.2017.01051a

Aclan, E., \& Abdul Aziz, N. (2015). Why and How EFL Students Learn Vocabulary in Parliamentary Debate Class. Advances in Language and Literary Studies, 6(1), 102-113. Retrieved from http://www.journals.aiac.org. au/index.php/alls/article/view/628. Doi:10.7575/aiac. alls.v.6n.1p.102

Adelodun, G. A., \& Asiru, A. B. (2015). Instructional Resources as Determinants of English Language Performance of Secondary School High-Achieving Students in Ibadan, Oyo State. Journal of Education and Practice, 6(21), 195-200.

Akmal, A. (2018). The Effect of Role-Play Method in English Speaking Skill. Journal of Science and Social Research, 1(1), 48-52.

Andi Prastowo. (2012). Panduan Kreatif Membuat Bahan Ajar Inovatif. Yogyakarta: Diva Press.

Andrade, A., Pereira, S., \& Tolo, A. (2018). Teaching Speaking by Using Communicative Approach to Second Year Students of Lower Secondary School Oecusse. ISCE: Journal of Innovative Studies on Character and Education, 2(1), 84-92.

Anzar, A., Anshari, A., \& Juanda, J. (2018). Research Material Development of Drama Appreciation Based on Local Wisdom on Student in Indonesian Literature and Language Education Program at Muhammadiyyah University of Makassar Indonesia. Journal of Language Teaching and Research, 9(1), 113-118. DOI: http://dx. doi.org/10.17507/jltr.0901.14
Atalay, O., \& Kahveci, N. G. (2015). An Experimental Study on Effectiveness of Integrated Curriculum Model (ICM) in Social Studies Education for Gifted and Talented Learners. Educational Research and Reviews, 10(8), 1049-1062. https://doi.org/10.5897/ERR2015.2151

Bndaka, E. (2007). Using newspaper Articles to Develop students' Reading Skills in Senior High School. The Reading Matrix, 7(1).

Borg, W.R. \& Gall, M.D. Gall. (2011). Educational Research: An Introduction, Fifth Edition. New York: Longman Depdiknas (2006) Kurikulum Tingkat Satuan Pendidikan. Jakarta: Depdiknas

Durrani, H. (2016). Attitudes of Undergraduates towards Grammar Translation Method and Communicative Language Teaching in EFL Context: A Case Study of SBK Women's University Quetta, Pakistan. Advances in Language and Literary Studies, 7(4), 167-172. Retrieved from http://www.journals.aiac.org.au/index.php/alls/ article/view/2499/2178.: http://dx.doi.org/10.7575/aiac. alls.v.7n.4p. 167

Doğan, G. \& Mirici, İ. H. (2017). EFL instructors' perception and practices on learner autonomy in some Turkish universities. Journal of Language and Linguistic Studies, 13(1), 166-193.

Etemadzadeh, A., Seifi, S., \& Far, H. R. (2013). The Role of Questioning Technique in developing thinking Skills: The Ongoing Effect on Writing Skill. Procedia - Social and Behavioral Sciences, 70, 1024-1031. doi:10.1016/j. sbspro.2013.01.154

Fauzi, I., \& Raya, F. U. P. (2018). The Effectiveness of Skimming and Scanning Strategies in Improving Comprehension and Reading Speed Rates to Students of English Study Programme. Register Journal, 11(1), 101120. doi: http://dx.doi.org/10.18326/rgt.v11i1.75-90

Fenwick, L. (2017). Promoting assessment for learning through curriculum-based performance standards: teacher responses in the Northern Territory of Australia, 5176(January). https://doi.org/10.1080/09585176.2016. 1260486

Gilmore, A. (2007). Authentic materials and authenticity in foreign language learning. Language Teaching, 40(02), 97.doi:10.1017/s0261444807004144

Hanifa, R. (2018). EFL Published Materials: An Evaluation of English Textbooks for Junior High School in Indonesia. Advances in Language and Literary Studies, 9(2), 166-174. doi: http://dx.doi.org/10.7575/aiac. alls.v.9n.2p.166

Huda, M. (2017). The Use of Authentic Materials In Teaching English: Indonesia Teachers' Perspective In EFL Classes. People: International Journal of Social Sciences, 3(2). doi-https://dx.doi.org/10.20319/pijss.2017.32.19071927

Jabeen, S. S., Campus, D., International, D., \& City, A. (2014). Implementation of Communicative Approach, 7(8), 68-74. https://doi.org/10.5539/elt.v7n8p68

Kahveci, N. G., \& Atalay, Ö. (2015). Use of Integrated Curriculum Model (ICM) in Social Studies: Gifted and Talented Students' Conceptions. Eurasian Journal of Educational Research, 59, 91-112. http://dx.doi.org/10.14689/ ejer.2015.59.6 
LaMotte, M. (2018). The Integrated Approach Versus the Traditional Approach: Analyzing the Benefits of a Dance and Transportation Integrated Curriculum. Journal of Dance Education, 18(1), 23-32. https://doi.org/10 $.1080 / 15290824.2017 .1336667$

Lau, W. C. M., \& Grieshaber, S. (2018). School-based integrated curriculum: An integrated music approach in one Hong Kong kindergarten. British Journal of Music Education, 35(2), 133-152. https://doi.org/10.1017/ S0265051717000250

Lutfi, A. A., Sutopo, D., \& Rukmini, D. (2018). The Effectiveness of Simulation and Role-Play in Teaching Speaking for Students with Different Levels of Motivation. English Education Journal, 8(4), 489-498. https:// doi.org/10.15294/eej.v8i4.24828

Maanen, J. Van. (2011). Ethnography as Work: Some Rules of Engagement, (January), 218-234. https://doi. org/10.1111/j.1467-6486.2010.00980.x

Mafora, P., Phorabatho, T., Mafora, P., \& Phorabatho, T. (2017). Curriculum Change Implementation : Do Secondary School Principals Manage the Process ? Curriculum Change Implementation: Do Secondary School Principals Manage the Process ?, 73. https://doi.org/10 $.1080 / 09720073.2013 .11891298$

Machali, I. (2014). Kebijakan Perubahan Kurikulum 2013 dalam Menyongsong Indonesia Emas Tahun 2045. Jurnal Pendidikan Islam, 3(1), 71-94. doi: 10.14421/ jpi.2014.31.71-94

Marliasari, S. (2017). Teaching Reading Comprehension by Using Skimming and Scanning Techniques to the Tenth Grade Students of SMAN 1 Gelumbang. English Community Journal, 1(2), 109-122. DOI: https://doi. org/10.32502/ecj.v1i2.768

Menteri Pendidikan dan Kebudayaan Republik Indonesia. (2013). Peraturan Menteri Pendidikan Nasional Nomor 81 Tahun 2013 tentang Kurikulum 2013.

Mukalel, Joseph C (2007) Creative Appproaches to classroom teaching. New Delhi: Discovery Publishing House

Naeini, N. N., \& Shahrokhi, M. (2016). Relationship between gender and vocabulary teaching methodology among Iranian EFL children: A comparison of TPR and direct method. Advances in Language and Literary Studies, 7(1), 60-74. http://dx.doi.org/10.7575/aiac.alls.v.7n.1p.60

Mariyaningsih, N \& Hidayati, M (2018) Bukan kelas Biasa: Teori dan Praktek berbagai model dan Metode Pembelajaran menerapkan Inovasi Pembelajaran Di kelas-kelas Inspiratif. CV Keneka Group: Surakarta.

Palfreyman, D. (2003). Introduction: Culture and learner autonomy. In D. Palfreymanand R. C. Smith (Eds.), Learner autonomy across cultures: Language education perspectives (pp. 1-19), Basingstoke: Palgrave Macmillan

Pietarinen, J., Pyhältö, K., \& Soini, T. (2016). Large-scale curriculum reform in Finland - exploring the interrelation between implementation strategy, the function of the reform, and curriculum coherence, 5176(May). https://doi.org/10.1080/09585176.2016.1179205

Purnawati, S., Fauzan, A., \& Rasidin, S. (2019, January). Contextual Learning Styles-Based Approach to Improve Mathematics Learning Outcomes In Primary School.
In International Conference on Islamic Education (ICoIE 2018). Atlantis Press. https://doi.org/10.2991/ icoie-18.2019.18

Ruhimat, Toto. dkk (2011). Kurikulum dan Pembelajaran. Jakarta: PT Raja Grafindo

Rukayah, R., Tolla, A., \& Ramly, R. (2018). The Development of Writing Poetry Teaching Materials Based on Audiovisual Media of Fifth Grade Elementary School in Bone Regency. Journal of Language Teaching and Research, 9(2), 358-366. http://dx.doi.org/10.17507/jltr.0902.18

Sanjaya, Wina. (2008). Kurikulum Dan Pembelajaran (Teori \& Praktek KTSP). Kencana

Song, L. (2018). Curriculum Reform Method in Colleges and Universities. Cognitive Systems Research, (September). https://doi.org/10.1016/j.cogsys.2018.09.004

Spradley, J. P. (1980). Participant observation. New York: Holt, Rinehart and Winsto

Suryadi, B., Ekayanti, F., \& Amalia, E. (2018). An Integrated Curriculum at an Islamic University: Perceptions of Students and Lecturers. Eurasian Journal of Educational Research, 18(74), 25-40. doi: 10.14689/ejer.2018.74.2

Fuhui Tong, Beverly J. Irby, Rafael Lara-Alecio \& Janice Koch (2014) Integrating Literacy and Science for English Language Learners: From Learning-to-Read to Reading-to-Learn, The Journal of Educational Research, 107:5, 410-426, doi: 10.1080/00220671.2013.833072

Ulaş, A. H., Sevim, O., \& Tan, E. (2012). The effect of worksheets based upon 5e learning cycle model on student success in teaching of adjectives as grammatical components. Procedia-Social and Behavioral Sciences, 31, 391-398. https://doi.org/10.1016/j.sbspro.2011.12.072

Ünal, S., Çeliköz, N., \& Sarı, İ. (2017). EFL Proficiency in Language Learning and Learner Autonomy Perceptions of Turkish Learners, 8(11), 117-122.

Vidergor, H. E., Givon, M., \& Mendel, E. (2019). Promoting future thinking in elementary and middle school applying the Multidimensional Curriculum Model. Thinking Skills and Creativity, 31(March 2018), 19-30. https:// doi.org/10.1016/j.tsc.2018.10.001

Wong, P., \& Cheung, A. (2015). The adoption features of government initiatives for the Curriculum Reform in Hong Kong schools, 43(5), 828-849. https://doi. org/10.1177/1741143214535743

Yusuf, H. O. (2014). Assessment of The Implementation of The Reading Component of The English Language Curriculum For Basic Education in Nigeria. Advances in Language and Literary Studies, 5(2), 96-102. http:// dx.doi.org/10.7575/aiac.alls.v.5n.2p.96

Yusuf, Q., Yusuf, Y. Q., Yusuf, B., \& Nadya, A. (2017). Skimming and Scanning Techniques to Assist EFL Students in understanding English reading texts. Indonesian Research Journal in Education| IRJE|, 43-57. https://doi. org/10.22437/irje.v1i1.4338

Zhao, W., Ah, I., Mok, C., \& Cao, Y. (2016). Curriculum reform in China : student participation in classrooms using a reformed instructional model. International Journal of Educational Research, 75(9), 88-101. https://doi. org/10.1016/j.ijer.2015.10.005 